\title{
Dead or alive? A large fraction of ETS-inactive marine bacterioplankton cells, as assessed by reduction of CTC, can become ETS-active with incubation and substrate addition
}

\author{
Joon W. Choi*, Barry F. Sherr**, Evelyn B. Sherr \\ College of Oceanic and Atmospheric Sciences, Oregon State University, 104 Ocean Admin, Corvallis, Oregon 97331-5503, USA
}

\begin{abstract}
The majority of bacteria suspended in seawater do not appear to be metabolically active or in good physiological condition as assessed by various methods. We tested the idea that a large fraction of 'inactive' bacterial cells can become 'active' with respect to detectable cell-specific electron transport system (ETS) activity, determined by the ability of cells to reduce the fluorogenic tetrazolium salt, CTC, when incubated for periods of time with or without additional substrate. Aliquots of $1.0 \mu \mathrm{m}$ filtered seawater were amended with mixed antibiotics to inhibit DNA synthesis and thus cell division, and incubated at in situ $\left(12.8\right.$ and $\left.16.4^{\circ} \mathrm{C}\right)$ temperature or at $20^{\circ} \mathrm{C}$. Additions included: phosphate

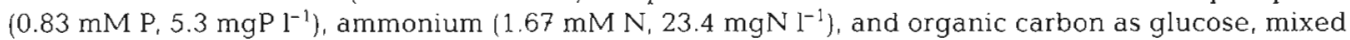
amino acids or yeast extract $\left(8.33 \mathrm{mM} \mathrm{C}, 100 \mathrm{mgC} \mathrm{l}^{-1}\right)$. At $20^{\circ} \mathrm{C}$, the addition of mixed amino acids and yeast extract resulted in a large increase of \% ETS-active cells [CTC-positive [CTC+] cells), from $1.9-2.4 \%$ at $0 \mathrm{~h}$ to $55-87 \%$ CTC+ cells by 21 to $28 \mathrm{~h}$. At in situ temperature, the increase in \% CTC+ cells was less, and the glucose addition caused the greatest increase in \% CTC+ cells. Under conditions of increased temperature and high concentration of organic substrate, a large proportion of the apparently 'inactive' bacteria can become highly ETS-active within a day, suggesting that these cells are in fact alive, and are capable of attaining significant metabolic activity. The different response patterns of the bacterial assemblages at $20^{\circ} \mathrm{C}$ compared to those at 12.8 and $16.4^{\circ} \mathrm{C}$ suggests that temperature can be an important factor in bacterioplankton response to increase in substrate concentration.
\end{abstract}

KEY WORDS: Bacteria $\cdot$ ETS $\cdot$ CTC $\cdot$ Metabolic activity $\cdot$ Temperature

\section{INTRODUCTION}

The question: what are the fractions of metabolically active, metabolically inactive, damaged, and dead cells in natural bacterioplankton assemblages, is one of past and current interest. Research on cell-specific properties of in situ bacteria has yielded conflicting results as to relative activity. Microautoradiography, in which cell-specific uptake of radiolabeled substrates added at $\mathrm{nM}$ concentrations is determined, has shown

\footnotetext{
- Present address: 2177 Crestview Avenue, Richland, Washington 99352, USA.

- Addressee for correspondence.

E-mail: sherrb@oce.orst.edu
}

that, in general, from 20 to $80 \%$ of cells in natural assemblages are able to take up radiolabeled amino acids (Tabor \& Neihof 1984, Douglas et al. 1987. Karner \& Fuhrman 1997). A number of fluorescent dyes that selectively enter either live, intact bacterial cells or dead or damaged bacteria have been used to separate living from moribund cells (e.g. Jepras et al. 1995, Lopez-Amoros et al. 1995, McFeters et al. 1995, Porter et al. 1995, Choi et al. 1996, del Giorgio et al. 1997b, Williams et al. 1997). When applied to natural fresh or salt waters, the results of these methods suggest that a widely variable fraction of aquatic bacteria is identifiable as membrane-damaged. Porter et al. (1995), testing a number of dyes that indicate membrane integrity, found that $93 \%$ of cells in oligotrophic 
lake water did not appear to be viable. Choi et al. (1996), using the Molecular Probes BacLight kit, scored as membrane damaged 78 to $93 \%$ of cells in samples collected in Oregon coastal seawater in late summer. Del Giorgio et al. ( 1997b), using Molecular Probes stains SYTO-13 and TOPRO- 1 for flow cytometric detection of total bacteria and membrane-damaged bacteria respectively, reported that only 10 to $15 \%$ of cells appeared to be damaged in the epilimnetic waters of a number of lakes. Using other approaches, Zweifel \& Hagström (1996) observed that from 68 to $98 \%$ of bacterioplankton did not appear to have DNA organized in a nucleoid region, and Heissenberger et al. (1996) found that in a free-living bacterial community $34 \%$ of cells appeared to be intact, $42 \%$ exhibited damaged cell walls and membranes, and $24 \%$ of cells appeared to lack any internal structure.

Zimmermann et al. (1978) proposed a method for determining the fraction of bacterial cells that were actively respiring via cell-specific reduction of a tetrazolium salt, 2-(4-iodophenyl)-3-(4-nitrophenyl)-5-phenyltetrazolium chloride (INT), to refractive crystals of formazan inside the cells. A variation of this method was developed by Rodriguez et al. (1992), in which a fluorogenic tetrazolium dye, 5-cyano-2,3-ditolyl tetrazolium chloride (CTC) was used instead of INT. CTC is a colorless, membrane permeable compound that produces a red-fluorescing precipitate when it is reduced by the electron transport system (ETS) of bacterial cells. Both INT, and more recently CTC, have been widely applied in freshwaters and in marine systems to determine the percentage of actively respiring bacteria (Tabor \& Neihof 1984, Newell et al. 1986, Dufour \& Colon 1992, del Giorgio \& Scarborough 1995, Gasol et al. 1995, del Giorgio et al. 1997, Posch et al. 1997).

Cells which reduce sufficient CTC to be scored as ETS-active, either microscopically or by flow cytometry, are unambiguously alive and capable of growth. Choi et al. (1996) reported that bacterial cells in exponential growth phase were nearly $100 \%$ CTC positive (CTC+). Using flow cytometry, del Giorgio et al. (1998) observed little or no overlap in bacterial cells with damaged membranes, as detected with the fluorescent stain TOPRO-1, and in bacterial cells capable of reducing CTC. Although there are reports of fractions of ETS-active cells greater than $50 \%$ in natural waters (del Giorgio \& Scarborough 1995), typically the proportion of bacterial cells exhibiting respiratory activity in freshly collected bacterial assemblages is $<10 \%$, and often is only a few to less than $1 \%$ (del Giorgio \& Scarborough 1995, Choi et al. 1996, Lovejoy et al. 1996, Karner \& Fuhrman 1997). In a survey of fraction of ETS-active cells in Atlantic shelf waters off Cape Hatteras, we found that the percentage of CTC+ bacteria was $10.3 \pm 2.5 \%$ at inshore stations and $4.4 \pm 1.0 \%$ at offshore stations (B. Sherr \& E. Sherr unpubl.). In a more recent 2 wk survey of bacterial parameters off the Oregon coast in August 1997, the percentage of CTC+ cells averaged $5.5 \pm 3.1 \%$, and ranged from 1.4 to $17.8 \%$ (B. Sherr \& E. Sherr unpubl. data). In such studies, whether the identifiable CTC+ cells are the only metabolically active cells in a bacterial assemblage has been an open question (del Giorgio \& Scarborough 1995). It has been suggested that the INT and CTC approach leads to underestimation of percent active cells because the tetrazolium salts are toxic to bacteria (Ullrich et al. 1996, Karner \& Fuhrman 1997).

The disparity among the various techniques used to assess bacterial cell activity and physiological condition in natural systems has caused uncertainty about how the results of each of these methods should be interpreted. In this study, we attempted to clarify the meaning of the CTC reduction assay by addressing the question: what proportion of initially CTC-negative (CTC-) bacteria in natural bacterioplankton assemblages can be induced to become visibly CTC+ by incubation and substrate addition? To do this, we assessed changes in \% CTC+ values for freshly collected coastal marine bacterioplankton in $1.0 \mu \mathrm{m}$ filtered water during incubations of from 1 to $5 \mathrm{~d}$. In 2 experiments, we also added antibiotics that inhibit DNA synthesis to retard bacterial growth and thus allow the initial bacterial cells a longer period to become highly ETS-active before an increase in cell abundance confounded the results. Our results showed that a large fraction (up to $87 \%$ ) of bacterial cells in the original assemblage could be induced, within a period of 20 to $30 \mathrm{~h}$, to exhibit high metabolic activity as indicated by detectable CTC reduction.

\section{METHODS}

Bacterial samples and cultures. Bacterioplankton assemblages in coastal seawater were collected from a jetty at the mouth of Yaquina Bay, Oregon, at high tide during spring, from the end of March to early June in 1996 and 1997. On each sampling date, several liters of whole seawater was returned to the laboratory and kept at the in situ collection temperature (from 12 to $16^{\circ} \mathrm{C}$ ) in the dark until processed for an experiment within $2 \mathrm{~d}$. Prior to an experiment, the seawater was gently screened through $1.0 \mu \mathrm{m}$ membrane filters by gravity filtration. For one of the preliminary experiments, we also used a month-old starved culture of a marine bacterial isolate Pseudomonas putida (Choi et a.. 1996).

Total bacterial abundance. Subsamples were fixed with $5 \%$ final volume of $37 \%$ borate-buffered formalin, stained with $25 \mu \mathrm{g} \mathrm{ml}^{-1}$ final concentration of DAPI 
for 5 min (Suzuki et al. 1993) and filtered onto $25 \mathrm{~mm}$, $0.2 \mu \mathrm{m}$ black-stained membrane filters. The filters were mounted onto slides and examined at $1250 \times$ with a Zeiss Universal microscope outfitted for epifluorescence microscopy, using Zeiss filter set 4877-02 (excitation $365 \mathrm{~nm} /$ barrier $420 \mathrm{~nm}$ ).

Cells with identifiably active electron transport systems (ETS). We used the fluorogenic tetrazolium dye CTC (Rodriguez et al. 1992) to detect bacteria with active ETS. A $50 \mathrm{mM} \mathrm{CTC} \mathrm{solution} \mathrm{was} \mathrm{prepared}$ according to Choi et al. (1996). In preliminary work, we found that the optimal concentration of CTC to maximize percent (\%) CTC+ cells can vary from 5 to $10 \mathrm{mM}$ At the beginning of each experiment, we tested seawater subsamples to optimize for concentration of CTC. We added $5 \mathrm{mM}$ final concentration CTC $(10 \mathrm{mM}$ in the June 1997 experiment) to $1 \mathrm{ml}$ aliquots of culture or seawater in $2.0 \mathrm{ml}$ cryogenic vials, and the samples with CTC were incubated at either $20^{\circ} \mathrm{C}$ or at in situ water temperature for $2 \mathrm{~h}$ in the dark. The samples were fixed with $5 \%$ final concentration formalin, counterstained with DAPI $\left(5 \mu \mathrm{g} \mathrm{ml}^{-1}\right)$, filtered onto $0.2 \mu \mathrm{m}$ black-stained membrane filters, and mounted onto slides. In some cases, we quick-froze the preserved samples in liquid nitrogen and stored the frozen samples at $-20^{\circ} \mathrm{C}$ until we were ready to complete processing. We have found that quick-freezing and frozen storage of liquid samples retains the percentage of CTC+ cells of the original sample for months, but that the number of CTC+ cells declines within days for samples mounted onto filters. Once CTC samples were mounted onto filters, we counted them within an hour. Bacterial cells were visualized at $1250 \times$ by DAPI fluorescence, then a green excitation filter set (Zeiss 4877 15, excitation $546 \mathrm{~nm} /$ barrier $590 \mathrm{~nm}$ ) was used to check each cell for red fluorescence of CTC. We have found that we can also easily identify orange CTC fluorescence using a blue light filter set (Zeiss 4777-09, excitation $365 \mathrm{~nm} /$ barrier $420 \mathrm{~nm}$ ).

Optimization of CTC concentration. Because recent papers have suggested that CTC, and in particular higher concentrations ( $>5 \mathrm{mM}$ ) of CTC, is toxic to bacteria (Lovejoy et al. 1996, Ullrich et al. 1996, Karner \& Fuhrman 1997), we carried out 2 preliminary experiments to check whether the CTC concentration we previously used (10 mM, Choi et al. 1996) was optimum for marine bacteria. We determined the \% ETSactive cells (CTC+ cells) as a function of CTC concentration from 1 to $20 \mathrm{mM}$. In the first experiment, we tested 1 mo old starved Pseudomonas putida; in the second we tested bacterioplankton in recently collected, $1.0 \mu \mathrm{m}$ filtered seawater. The samples with varying concentrations of CTC were incubated at $20^{\circ} \mathrm{C}$ for $2 \mathrm{~h}$. Based on the results of these experiments, and the results of CTC concentration optimization experi- ments carried out at the beginning of each of our induction experiments, we used a final concentration of $5 \mathrm{mM} \mathrm{CTC} \mathrm{(10} \mathrm{mM}$ in June 1997) in the rest of this study.

Optimization of substrate concentration. The primary object of our study was to determine the extent to which substrate addition increased the fraction of CTC+ cells in the original bacterial assemblage, before significant cell increase occurred. We carried out 3 experiments to determine what range of substrate concentration resulted in maximum increase in \% CTC+ for coastal bacterioplankton. We used yeast extract (YE) at concentrations of from 0.02 to $200 \mathrm{mg} \mathrm{C} \mathrm{l}^{-1}$ and $24 \mathrm{~h}$ incubations for these experiments. We had previously found that addition of a complex organic substrate resulted in enhancement of the proportion of ETS-active cells in natural bacterioplankton assemblages before increase in cell number was observed (Choi et al. 1996). In the third substrate optimization experiment, we also added a mixture of DNA synthesis inhibitors (see below) prior to adding the YE.

Induction experiments. Based on the results of the substrate optimization experiments, we used a carbon equivalent of $100 \mathrm{mg} \mathrm{C} \mathrm{l}^{-1}(8.33 \mathrm{mM} \mathrm{C}$ ) for the induction experiments. Organic substrates included glucose (Glu), a mixture of equal carbon-equivalents of 20 amino acids (AA), and YE. The amino acids used in the mixture were: alanine, arginine, asparagine, aspartic acid, cysteine, glutamine, glysine, histidine, hydroxproline, isoleucine, leucine, lysine, methionine, phenylalanine, proline, threonine, tryptophan, l-tyrosine, serine, and valine. To some treatments we also added phosphate $\left(0.83 \mathrm{mM} \mathrm{P}, 5.3 \mathrm{mg} \mathrm{P}^{-1}\right)$ and/or ammonium

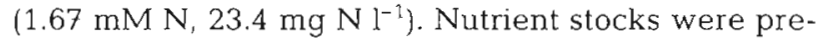
pared in filter-sterilized deionized water at concentrations 200-fold higher than final concentrations in experimental treatments. Experimental units consisted of $20 \mathrm{ml}$ aliquots of $1.0 \mu \mathrm{m}$ filtered seawater in $30 \mathrm{ml}$ autoclaved glass test tubes, loosely capped, amended with substrate as required, and placed in a rack in either a water bath held at $20^{\circ} \mathrm{C}$, or in an incubation chamber set at in situ temperature. We carried out a total of 3 induction experiments: 1 initial experiment without DNA synthesis inhibitors, and 2 experiments with inhibitors added.

Initial experiment without inhibitors: Seawater was collected on 30 March 1997. Treatments consisted of duplicate tubes of no addition control (C), Glu, + Glu+P, $+\mathrm{Glu}+\mathrm{N},+\mathrm{Glu}+\mathrm{N}+\mathrm{P},+\mathrm{AA},+\mathrm{AA}+\mathrm{P}$, and $+\mathrm{YE}$. All treatments were incubated at $20^{\circ} \mathrm{C}$ for $24 \mathrm{~h}$. Replicate samples were taken for bacterial abundance and for \% CTC + cells at time 0 and at $24 \mathrm{~h}$.

Experiments with added inhibitors: We suspected that some bacteria in the original seawater assemblage might take longer than $24 \mathrm{~h}$ to become identifiably 
CTC + , but based on previous experience (Choi et al. 1996), we knew that bacterial abundance in incubation experiments usually began to increase by 6 to $24 \mathrm{~h}$. We decided to perform further induction experiments in which we first added inhibitors of DNA synthesis to retard cell division. In this way, we could extend the induction experiments for a longer period of time without increase in \% CTC + cells being confounded by the production of newly produced, active daughter cells. We used the combination of inhibitors suggested by Kogure et al. $(1984,1987)$ : nalidixic acid (NA), pipemidic acid (PPA) and piromidic acid (PA). We did initial tests with varying strengths of this mixture of DNA synthesis inhibitors added to $1.0 \mu \mathrm{m}$ filtered seawater amended with $100 \mathrm{mg} \mathrm{Cl}^{-1} \mathrm{YE}$ and incubated at $20^{\circ} \mathrm{C}$. These tests showed that the inhibitor concentrations suggested by Kogure et al. (1984) were insufficient to keep cells exposed to added substrate from dividing for longer than 6 to $12 \mathrm{~h}$ periods. We eventually determined that an inhibitor mixture 5 times stronger that of Kogure et al. (1984): $10 \mathrm{mg}$ of NA $(0.01 \%), 5 \mathrm{mg}$ of PPA $(0.005 \%)$, and $5 \mathrm{mg}$ of PA $(0.005 \%)$ per $100 \mathrm{ml}$ of seawater, was sufficient to keep cells from dividing for periods of 21 to $33 \mathrm{~h}$ at $20^{\circ} \mathrm{C}$, depending on the substrates added.

Two induction experiments were carried out with added inhibitors: treatments were $\mathrm{C},+\mathrm{P},+\mathrm{N},+\mathrm{Glu}$, $+\mathrm{AA}$, and $+\mathrm{YE}$. Duplicate sample tubes were set up for each treatment. For the experiment in May 1997, separate sets of tubes were incubated at $20^{\circ} \mathrm{C}$ and at the in situ temperature, $12.8^{\circ} \mathrm{C}$. In the experiment in June 1997,2 sets of tubes were incubated at $20^{\circ} \mathrm{C}$ and at the in situ temperature of $16.4^{\circ} \mathrm{C}$. The experiments were sampled over time for total cell abundance and abundance of CTC+ cells for periods of 36 to $130 \mathrm{~h}$.

We also separately enumerated the number of bacterial cells that did not have observable CTC fluorescence in these experiments, i.e. the CTC-cells, by direct counts in each sample inspected. The estimates of CTC-abundance were thus an independent parameter rather than a derived parameter - i.e we did not calculate the abundance of CTC - cells by simple subtraction of the mean CTC+ cell number from the mean number of total bacteria.

\section{RESULTS}

\section{Optimum concentration of CTC}

The 2 tests we carried out, with a starved marine isolate and with freshly collected coastal bacterioplankton, showed a similar pattern of \% CTC+ cells versus concentration of CTC (Fig. 1). In both experiments, \% CTC+ increased from 1 to $5 \mathrm{mM}$ final concentration of
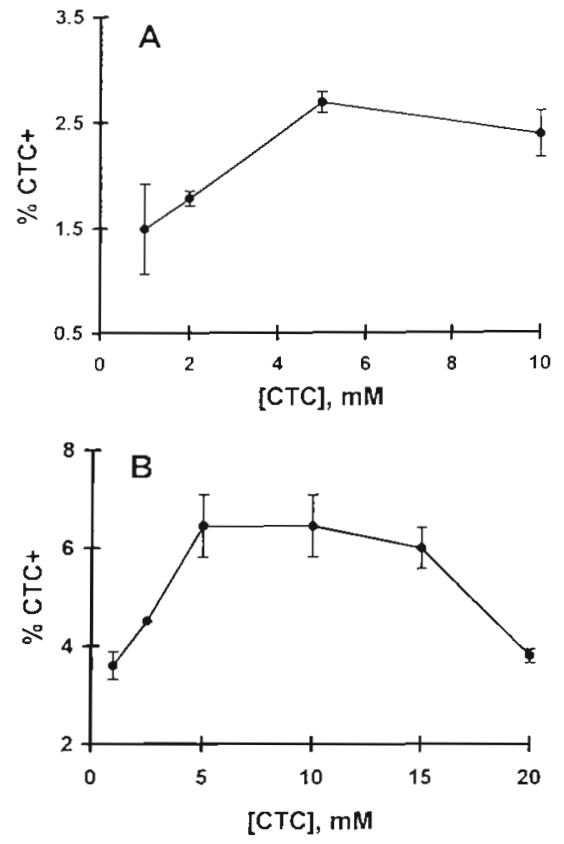

Fig. 1. Evaluation of percentage of bacteria identified as ETS active $(C T C+)$ as a function of CTC concentration for: (A) a I mo old starved culture of a marine bacterial isolate Pseudomonas putida, and (B) a mixed species bacterial assemblage in a freshly collected sample of seawater from the Oregon coast

CTC, and then remained constant at $10 \mathrm{mM} \mathrm{CTC}$. In the second experiment with natural bacterioplankton (Fig. 1B), there was a sharp decline in \% CTC cells at the $20 \mathrm{mM}$ concentration. Based on these results, we concluded that use of CTC concentrations of 5 to $10 \mathrm{mM}$ to determine the percent of cells exhibiting active ETS was justified, but that using CTC concentrations less than $5 \mathrm{mM}$ or greater than about $15 \mathrm{mM}$ could result in artefactually low values.

\section{Optimum concentration of organic substrate}

We expected to obtain significant enhancement of the percent of cells with high respiratory activity with addition of fairly low concentration ( $<10$ to $20 \mathrm{mg} \mathrm{Cl}^{-1}$ ) of YE. The results of the 3 experiments to determine the $\% \mathrm{CTC}+$ as a function of [YE] did not show such an effect, however (Table 1). In the May 23 experiment, there was no significant increase in \% CTC+ at [YE] < $20 \mathrm{mg} \mathrm{Cl}{ }^{-1}$, and the highest \% CTC+ value, $16.8 \%$, was found for the $100 \mathrm{mg} \mathrm{Cl}^{-1}$ addition. In the May 27 experiment, highest \% CTC+ was obtained at $80 \mathrm{mg} \mathrm{C}$ $\mathrm{l}^{-1}$, however at $200 \mathrm{mg} \mathrm{Cl}^{-1}, \% \mathrm{CTC}+$ dropped to a value lower than that of the smallest addition of $\mathrm{YE}$. For the April experiment, in which DNA synthesis inhibitors were also added, marked enhancement of 
Table 1. Effect of varying addition of yeast extract (YE) on the percentage of CTC+ cells for coastal bacterioplankton assemblages in $1.0 \mu \mathrm{m}$ filtered water incubated at $20^{\circ} \mathrm{C}$ for $24 \mathrm{~h}$. DNA synthesis inhibitors were added to all treatments in the April 1997 experiment. Values are means of 2 replicate tubes \pm 1 standard deviation, where indicated

\begin{tabular}{|lc|}
\hline mg YE C ${ }^{-1}$ & $\%$ CTC + bacteria \\
\hline May 23, 1996 & \\
0.02 & $2.2 \pm 0.6$ \\
0.20 & $2.8 \pm 0.7$ \\
2.0 & $3.5 \pm 1.4$ \\
20 & $7.4 \pm 1.6$ \\
100 & $16.8 \pm 1.8$ \\
& \\
May 27, 1996 & \\
0.02 & 11.8 \\
2.0 & 19.8 \\
20 & 20.1 \\
80 & 32.2 \\
200 & 8.1 \\
April 11, 1997 & \\
0 & \\
0.02 & $2.6 \pm 1.1$ \\
0.20 & $3.6 \pm 0.6$ \\
2.0 & 2.9 \\
10 & $4.0 \pm 0.4$ \\
25 & $4.2 \pm 1.0$ \\
50 & $4.2 \pm 0.2$ \\
100 & $7.9 \pm 1.2$ \\
150 & $9.1 \pm 2.8$ \\
200 & $19.5 \pm 5.9$ \\
& $15.2 \pm 5.2$ \\
\hline
\end{tabular}

the fraction of ETS-active cells did not occur until an addition of $50 \mathrm{mg} \mathrm{Cl}^{-1}$ of $\mathrm{YE}$, and the 2 highest values were found for the 150 and $200 \mathrm{mg} \mathrm{C} \mathrm{l}^{-1}$ additions (Table 1). Based on these results, we chose a concentration of organic substrate of $100 \mathrm{mg} \mathrm{C} \mathrm{l}^{-1}$ for subsequent induction experiments.

\section{Results of initial induction experiment}

The first induction experiment in April 1997 did not have added DNA synthesis inhibitors and was sampled at only 2 time points, 0 and $24 \mathrm{~h}$. In this experiment, we examined the extent to which addition of inorganic nutrients, glucose, glucose plus inorganic nutrients, mixed amino acids, mixed amino acids plus phosphorus, and yeast extract could enhance the percentage of ETS-active cells as determined by visible reduction of CTC. Bacterial growth was not observed in any of the treatments. The time 0 bacterial abundance was $3.3 \times$ $10^{5}$ cells $\mathrm{ml}^{-1}$. At $24 \mathrm{~h}$, bacterial abundance in the control was $2.8 \times 10^{5} \mathrm{ml}^{-1}$, and in the addition treatments abundance ranged from 2.2 to $2.9 \times 10^{5} \mathrm{ml}^{-1}$. Addition of yeast extract resulted in the highest number of
CTC + cells (51\% of total bacteria) (Fig. 1). Mixed amino acids, with or without added phosphate, yielded 31 to $32.5 \%$ CTC+ cells, and glucose plus ammonium and phosphate a smaller percentage, $7.6 \% \mathrm{CTC}+$. In the rest of the treatments, \% CTC+ was the same as, or less than, the control value of $4.3 \%$ (Fig, 2).

\section{Results of induction experiments with inhibitors}

The experiments of May and June 1997 had a mix ture of DNA synthesis inhibitors added to retard cell division and were each carried out at 2 different temperatures: $20^{\circ} \mathrm{C}$ and in situ temperature. Parameters sampled over time were total bacterial abundance, abundance of CTC+ cells, and abundance of CTCcells. Due to the greater number of sampling times in these experiments ( 7 to 8 time points for each of the treatments), the number of treatments was less than used in the initial induction experiment. Treatments consisted of a control and separate additions of ammonium, phosphate, glucose, mixed amino acids, and yeast extract.

For those treatments in which the abundance of $\mathrm{CTC}+$ cells increased compared to the time 0 value, we observed 2 patterns. At $20^{\circ} \mathrm{C}, \% \mathrm{CTC}+$ began to rise by 10 to $23 \mathrm{~h}$, and the total cell number began to increase after 21 to $33 \mathrm{~h}$ (Table 2, Fig. 3). The proportion of ETSactive cells increased rapidly just prior to onset of exponential growth (Fig. 3). For this reason, we report

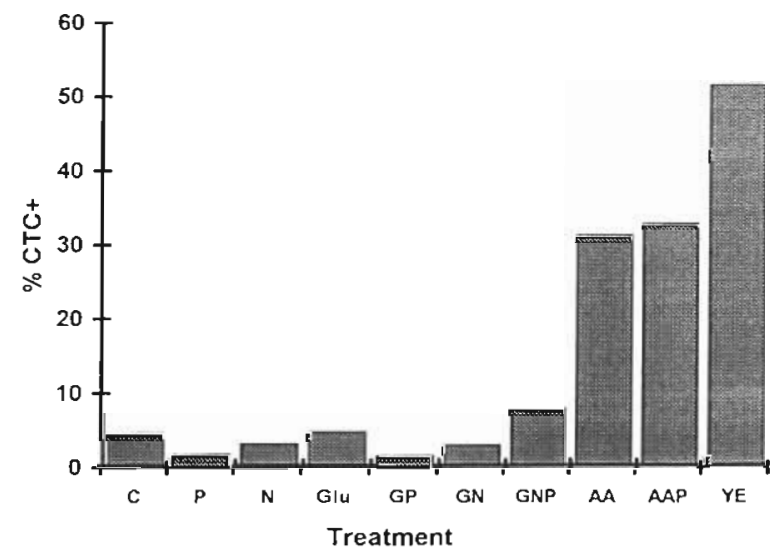

Fig. 2. Effect of substrate addition on induction of identifiable ETS activity, via reduction of CTC, for coastal marine bacteria sampled in March 1997. Treatments included addition of phosphorus (0.83 mM P. $\left.5.3 \mathrm{mg} \mathrm{P} \mathrm{l}^{-1}\right)$, ammonium (1.67 mM , $\left.23.4 \mathrm{mg} \mathrm{N}^{-1}\right)$, and of $100 \mathrm{mg} \mathrm{Cl}^{-1}(8.33 \mathrm{mM} \mathrm{C})$ organic substrates: glucose (Glu, or G), a mixture of equal carbon-equivalents of 20 amino acids (AA), and yeast extract (YE). Duplicate sample tubes for each treatment were held at $20^{\circ} \mathrm{C}$ in the dark for $24 \mathrm{~h}$ before sampling for abundance of total bacteria and of CTC+ bacteria. Values are means for each treatment. DNA synthesis inhibitors were not added in this initial induction experiment 
here the highest \% CTC+ values that were obtained just at the beginning of exponential growth, when the cell abundance had increased to only 112 to $180 \%$ of the time 0 bacterial abundance (Table 2). At the same time, the number of CTC-cells decreased, in some cases to a very low abundance (Fig. 3).

At in situ temperature, a different pattern emerged. Increase in both number of CTC+ and of total cells was much slower, and did not occur until after 72 to $107 \mathrm{~h}$ of incubation (Table 2, Fig. 4). The maximum increase in CTC+ cells, and the decrease in number of CTC-cells, before onset of exponential growth were less compared to the results of the experiments at $20^{\circ} \mathrm{C}$. Also, at in situ temperature the number of CTC-cells began to increase as total cell number increased (Fig. 4); while typically at $20^{\circ} \mathrm{C}$ the number of CTC-cells declined to a low value and showed no subsequent rise with increase in total cell number (Fig. 4).

Table 2 presents a summary of the maximum increase in \% CTC+ cells at the beginning of exponen-
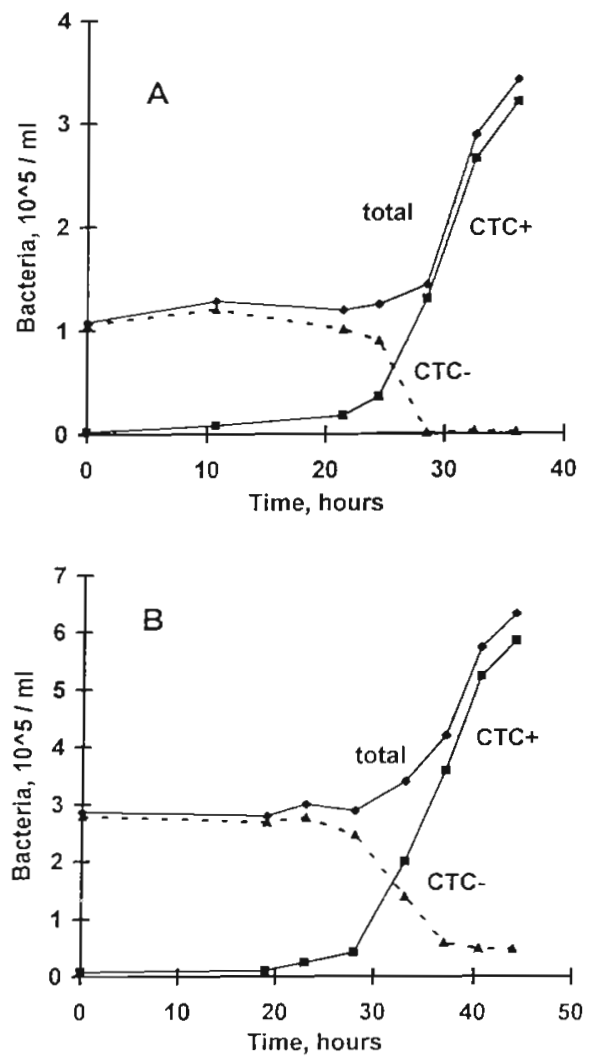

Fig. 3. Examples of full time course data sets of abundances $\left(10^{5}\right.$ cells $\left.\mathrm{ml}^{-1}\right)$ of total bacteria $(\bullet)$, of CTC-positive bacteria $(\boldsymbol{m})$, and of CTC-negative bacteria $(---, 4)$ for $20^{\circ} \mathrm{C}$ treatments in the induction experinents with added inhibitors: (A) May 1997, yeast extract addition, $20^{\circ} \mathrm{C}$, and (B) June 1997, yeast extract addition, $20^{\circ} \mathrm{C}$. Values are means for 2 replicate tubes for each treatment; coefficients of variation were $<30 \%$. See Tables 2 \& 3 for summary data for all treatments in these 2 experiments with added inhibitors tial growth in the induction experiments. At $20^{\circ} \mathrm{C}$, we did not sample the yeast extract treatments frequently enough to catch the point at which numbers of CTC+ cells were high but cell abundance had not yet doubled. At the higher temperature, the percentage of $\mathrm{CTC}+$ cells rose by more than an order of magnitude in both control and addition treatments compared to the time 0 values of $1.9 \%$ in May and $2.4 \%$ in June. At $20^{\circ} \mathrm{C}$ only the amino acid and yeast extract additions caused a higher percentage of CTC+ cells compared to the control (Table 2). In May, the ammonium and glucose addition treatments had lower \% CTC+ values compared to the other treatments.

At the in situ temperatures of $12.8^{\circ} \mathrm{C}$ in May and $16.4^{\circ} \mathrm{C}$ in June, the bacterioplankton assemblage responded quite differently (Table 2). The increase in $\%$ CTC+ cells was less, addition of amino acids or of yeast extract appeared to be inhibitory at $12.8^{\circ} \mathrm{C}$, and the addition of amino acids was inhibitory at $16.4^{\circ} \mathrm{C}$. The only clear substrate enhancement of the propor-
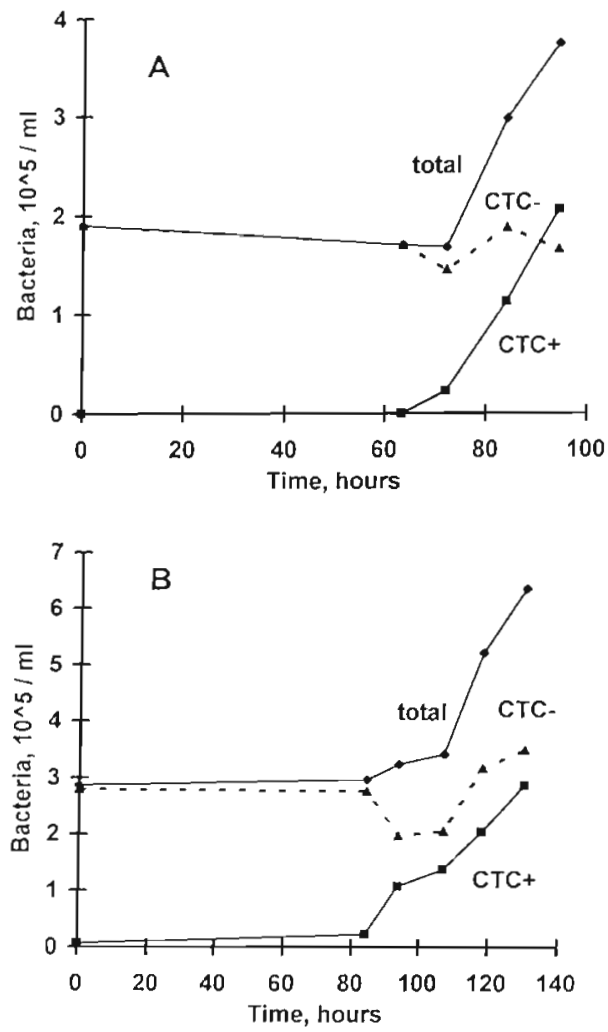

Fig. 4. Examples of full time course data sets of abundances $\left(10^{5}\right.$ cells $\left.\mathrm{ml}^{-1}\right)$ of total bacteria ( $\left.\bullet\right)$, of CTC-positive bacteria (-), and of CTC-negative bacteria $(--,, 4)$ for in situ temperature treatments in the induction experiments with added inhibitors: (A) May 1997, $12.8^{\circ} \mathrm{C}$, glucose addition, and (B) June $1.997,16.4^{\circ} \mathrm{C}$, glucose addition. Values are means for 2 replicate tubes for each treatment; coefficients of variation were $<30 \%$. See Tables $2 \& 3$ for summary data for all treatments in these 2 experiments with inhibitors 
tion of identifiable ETS-active cells at the colder temperatures was found in the June experiment, in response to glucose addition (Table 2).

Since in the experiments with inhibitors the increase in \% CTC+ cells was still confounded to some extent by cell growth, we also indirectly estimated the proportion of time 0 cells that became CTC+. To do this, we used the decrease in CTCcells, which was independently determined by direct counts of CTC- cells in the samples. The minimum number of CTC-cells that was found for each treatment during the time series sampling was subtracted from the time 0 bacterial abundances (1.08 and $1.90 \times$ $10^{5} \mathrm{ml}^{-1}$ in May and $2.86 \times 10^{5} \mathrm{ml}^{-1}$ in June). The difference was assumed to be the number of bacteria originally present in the assemblage that became CTC+ during the incubation. In 2 treatments: May $12.8^{\circ} \mathrm{C}$, +Glu and $+\mathrm{AA}$, the total number of bacteria decreased over time (Table 2). For these treatments, we subtracted the minimum number of CTC-cells from the total bacterial abundance at that time, and used these abundances rather than the time 0 abundances to calculate the maximum \% CTC+ cells.

The results of the indirect calculation of maximum induction of high respiratory activity (Table 3 ) showed a fairly similar pattern compared to the direct results in Table 2. The highest \% CTC+ values estimated indirectly were lower in some cases, particularly for the yeast extract treatments at $20^{\circ} \mathrm{C}$. The treatments that showed greatest induction of respiratory activity compared to the control were addition of amino acids, and to a lesser extent, of yeast extract, at $20^{\circ} \mathrm{C}$, and addition of glucose at $16.4^{\circ} \mathrm{C}$. At the lower temperatures, the yeast extract and amino acid additions appeared to be inhibitory (Table 3 ).

In all 3 induction experiments, we included treatments with additions of phosphate and ammonium based on field and laboratory work that suggested growth of marine bacteria
Table 2. Maximum increase in percentage of $\mathrm{CTC}+$ cells in the 2 induction experiments with added DNA synthesis inhibitors (May and June 1997) before the abundance of bacteria doubled, i.e. at the beginning of exponential growth. Organic substrate addition consisted of glucose (+Glu), a mixture of equal carbon-equivalents of 22 amino acids (+AA), or yeast extract (+YE) added at $100 \mathrm{mg}$ $\mathrm{C}^{-1}(8.33 \mathrm{mM})$. In the $+\mathrm{P}$ and $+\mathrm{N}$ treatments, we added phosphorus $10.83 \mathrm{mM}$, $5.3 \mathrm{mg} \mathrm{P}^{-1}$ ) or ammonium (1.67 mM, $\left.23.4 \mathrm{mg} \mathrm{N}^{-1}\right)$. Values are means from 2 replicate tubes for each treatment, coefficient of variation was $<30 \%$

\begin{tabular}{|c|c|c|c|c|c|c|}
\hline Treatment & $\begin{array}{c}\text { Time } \\
\left.\text { (h from } T_{0}\right)\end{array}$ & $\begin{array}{c}\text { Bacteria } \\
\left(10^{5} \mathrm{ml}^{-1}\right)\end{array}$ & $\begin{array}{c}\% \\
\text { CTC+ }\end{array}$ & $\begin{array}{c}\text { Time } \\
\left(\mathrm{h} \text { from } T_{0}\right)\end{array}$ & $\begin{array}{c}\text { Bacteria } \\
\left(10^{5} \mathrm{ml}^{-1}\right)\end{array}$ & $\begin{array}{c}\% \\
\text { CTC+ }\end{array}$ \\
\hline May 1997 & & $20.0^{\circ} \mathrm{C}$ & & & $12.8^{\circ} \mathrm{C}$ & \\
\hline Control & 0 & 1.08 & 1.9 & 0 & 1.90 & 0 \\
\hline Control & 21.5 & 1.83 & 60.9 & 84 & 1.81 & 32.1 \\
\hline$+\mathrm{P}$ & 24.5 & 1.63 & 60.5 & 94.3 & 1.89 & 34.2 \\
\hline$+N$ & 24.5 & 1.41 & 48.4 & 94.3 & 1.9 & 14.6 \\
\hline +Glu & 21.5 & 1.34 & 47.7 & 72 & 1.68 & 13.7 \\
\hline$+\mathrm{AA}$ & 28.5 & 1.44 & 90.5 & 94.3 & 1.72 & 0 \\
\hline$+Y E$ & 21.5 & 6.96 & 93.1 & 94.3 & 1.97 & 0 \\
\hline June 1997 & & $20.0^{\circ} \mathrm{C}$ & & & $16.0^{\circ} \mathrm{C}$ & \\
\hline Control & 0 & 2.86 & 2.4 & 0 & 2.86 & 2.4 \\
\hline Control & 28 & 3.20 & 34.8 & 107 & 2.94 & 13.6 \\
\hline$+\mathrm{P}$ & 33 & 3.20 & 35.9 & 107 & 3.15 & 11.5 \\
\hline$+N$ & 28 & 3.29 & 24.7 & 107 & 2.83 & 13.8 \\
\hline +Glu & 28 & 3.24 & 35.7 & 93.6 & 3.24 & 39.6 \\
\hline$+\mathrm{AA}$ & 33 & 3.4 & 58.9 & 130 & 3.08 & 2.2 \\
\hline$+\mathrm{YE}$ & 28 & 5.37 & 78.9 & 93.6 & 3.16 & 13.1 \\
\hline
\end{tabular}

Table 3. Indirect estimation of maximum increase in percent CTC+ for cells present at $T_{0}$ from the minimum number of CTC-negative cells (min CTC-) observed during the May and June 1997 experiments with added inhibitors. Percent CTC + was estimated by: $\left(\left[T_{0}\right.\right.$ bacteria $-\{$ min CTC -$\left.\}\right] / T_{0}$ bacteria $) \times 100$. In this case, hours from $T_{0}$ indicates the time at which the minimum number of CTC-cells was observed. In some cases, the minimum number of CTC-cells was found later than the maximum number of CTC+ cells before cell abundance doubled, as shown in Table 2. $T_{0}$ bacterial abundances for each of the experiments are presented in Table 2 . Values are means from 2 replicate tubes for each treatment, coefficient of variation was $<30 \%$

\begin{tabular}{|c|c|c|c|c|c|c|}
\hline Treatment & $\begin{array}{c}\text { Time } \\
\text { (h from } T\end{array}$ & $\begin{array}{c}\min \text { CTC- } \\
\left.\Gamma_{0}\right)\left(10^{5} \mathrm{ml}^{-1}\right)\end{array}$ & $\stackrel{\%}{\%}$ & $\begin{array}{c}\text { Time } \\
\text { (h from } T_{0} \text { ) }\end{array}$ & $\begin{array}{l}\min \text { CTC- } \\
\text { 0) }\left(10^{5} \mathrm{ml}^{-1}\right)\end{array}$ & $\stackrel{\%}{\mathrm{CTC}+}$ \\
\hline May 1997 & \multicolumn{3}{|c|}{$20.0^{\circ} \mathrm{C}$} & \multicolumn{3}{|c|}{$12.8^{\circ} \mathrm{C}$} \\
\hline Control & 0 & 1.06 & 1.9 & 0 & 1.90 & 0 \\
\hline Control & 24.5 & 0.72 & 33.3 & 84 & 1.23 & 35.3 \\
\hline$+P$ & 36.0 & 0.53 & 50.9 & 94.3 & 1.26 & 33.7 \\
\hline$+\mathrm{N}$ & 28.5 & 0.54 & 50.0 & 94.3 & 1.63 & 14.2 \\
\hline +Glu & 24.5 & 0.53 & 50.9 & 72 & 1.45 & 13.7 \\
\hline$+\mathrm{AA}$ & 28.5 & 0.14 & 87.0 & 94.3 & 1.72 & 0 \\
\hline$+Y E$ & 21.5 & 0.48 & 55.6 & 94.3 & 1.97 & 0 \\
\hline June 1997 & \multicolumn{3}{|c|}{$20.0^{\circ} \mathrm{C}$} & \multicolumn{3}{|c|}{$16.0^{\circ} \mathrm{C}$} \\
\hline Control & 0 & 2.79 & 2.4 & 0 & 2.79 & 2.4 \\
\hline Control & 44 & 1.47 & 48.6 & 107 & 2.53 & 11.5 \\
\hline$+\mathrm{P}$ & 40.5 & 1.38 & 51.7 & 107 & 2.72 & 4.9 \\
\hline$+\mathrm{N}$ & 30.7 & 1.72 & 39.9 & 107 & 2.44 & 14.7 \\
\hline+ Glu & 37 & 1.51 & 47.2 & 93.6 & 2.01 & 29.7 \\
\hline$+\mathrm{AA}$ & 44 & 0.48 & 83.2 & 130 & 2.79 & 2.4 \\
\hline$+Y E$ & 28 & 1.13 & 60.5 & 93.6 & 2.74 & 4.2 \\
\hline
\end{tabular}


could be limited by availability of inorganic nutrients as well as of organic substrate (reviewed in Kirchman 1994). However, in these experiments we found no evidence that either phosphate or ammonium enhanced the increase in ETS-active cells compared to the noaddition controls.

\section{DISCUSSION}

A number of studies to examine bottom-up (i.e. substrate) control of bacterial growth in marine systems have included 'substrate-responsiveness' experiments, in which bacterial response to added substrate of known quality and quantity is assessed. In most such studies, bacterial biomass increase, growth rate and/or utilization of DOC and oxygen has been monitored over 1 or more days (e.g. Coffin et al. 1993 Shiah \& Ducklow 1994, Carlson \& Ducklow 1996, Cherrier et al. 1996). One problem with such 'growup' studies is that the bacterial response may be due to only a portion of the bacterial assemblage, and those bacteria that grow in response to nutrient addition may not be characteristic of the in situ assemblage. The goal of our study was to evaluate what fraction of bacterioplankton initially present in a sample was capable of becoming detectable as having ETS activity using the CTC method. Kogure et al. (1987) and Joux \& LeBaron (1997) have previously investigated this question using DNA synthesis inhibitors and added organic substrates to evaluate the proportion of bacterioplankton that showed cell enlargement with added substrate (the direct viable count or DVC method). We used the CTC approach in our study, which in our opinion is a more sensitive and less ambiguous method for identifying actively metabolizing cells than is the DVC method.

There has been some question as to whether the CTC method yields anomalously low estimates of percent ETS-active cells due to toxic effects of CTC (Lovejoy et al. 1996, Ullrich et al. 1996, Karner \& Fuhrman 1997). Ullrich et al. (1996) found that CTC concentrations in the range of 1 to $10 \mathrm{mM}$ dramatically suppressed bacterial plate counts, cell growth rate, and respiration rates. Karner \& Fuhrman (1997) reported that 2 other estimates of the number of active cells: cell-specific substrate uptake via microautoradiography and the cell-specific amount of ribosomal RNA, gave much higher values compared to number of CTC+ cells.

We examined the effect of CTC concentration on the proportion of CTC+ cells for a starved bacterial isolate and for a coastal bacterioplankton assemblage. In both cases (Fig. 1), the proportion of CTC+ cells was maximum at $5 \mathrm{mM}$ CTC. Toxicity, as evidenced by decreased \% CTC+ cells, was only observed at $20 \mathrm{mM}$ CTC for the bacterioplankton assemblage (Fig. 1B). Five mM CTC has been used to assess \% ETS-active bacteria in a number of aquatic systems (Rodriguez et al. 1992, del Giorgio \& Scarborough 1995, del Giorgio et al. 1996, 1997b). Del Giorgio et al. (1997) recently evaluated the number of CTC+ cells as a function of CTC concentration for bacteria in lakes, and judged that $5 \mathrm{mM}$ was the optimum concentration in their study. These results, in combination with the high values for \% CTC+ cells we obtained with incubation time and nutrient enrichment, suggest to us that CTC toxicity does not cause serious underestimation of the abundance of highly ETS-active bacterial cells. However, using a CTC concentration lower than $5 \mathrm{mM}$, as did Lovejoy et al. (1996) and Karner \& Fuhrman (1997), could result in artefactually low estimates of \% ETSactive cells. It is also likely that some bacterial cells have such low metabolic activity that insufficient CTC is reduced to be visible microscopically. Del Giorgio et al. $(1997 \mathrm{a}, \mathrm{b})$ have found flow cytometry to be more sensitive in detecting CTC+ cells compared to microscopy.

Of surprise to us in the induction experiments was the relatively high concentration of organic substrate, $100 \mathrm{mg} \mathrm{C} \mathrm{l}^{-1}$, required to obtain the greatest increase in the number of bacterial cells scored as ETS active (Table 1). In other studies, organic substrate additions have been in the general range of 0.1 to $40 \mathrm{mg} \mathrm{C} \mathrm{l}^{-1}$ (Kogure et al. 1987, Kirchman 1990, Coffin et al. 1993, Shiah \& Ducklow 1994, Carlson \& Ducklow 1996, Cherrier et al. 1996). There is evidence that for cells in starvation-survival mode, exposure to high substrate concentration can cause cell death (Koch 1997). At $20^{\circ} \mathrm{C}$, the results did not show a negative effect of $100 \mathrm{mg} \mathrm{Cl}^{-1}$ substrate concentration on the proportion of ETS-active cells (Figs. 2 \& 3, Tables 1 to 3 ). There did appear to be a detrimental effect on the percentage of ETS-active cells due to addition of high concentrations of amino acids and yeast extract at in situ temperature (Tables $2 \& 3$ ). At $12.8^{\circ} \mathrm{C}$, both the amino acid and yeast extract treatments resulted in undetectable numbers of CTC+ cells, and at $16.4^{\circ} \mathrm{C}$, the amino acids addition resulted in no increase in percentage of CTC+ cells during the incubations (Table 2). We have no present explanation for the apparent inhibitory effect of these substrates at in situ temperature.

In order to delay the onset of cell growth for longer than 12 to $24 h$, we used concentrations of the inhibitors nalidixic acid, piromidic acid, and pipemidic acid 5 -fold stronger than recommended by Kogure et al. (1984). Joux \& LeBaron (1997) have recently formulated a mixture of 5 different antibiotics: the 3 suggested by Kogure et al. (1984) plus cipofloxacin and cephalexin, which was found to inhibit DNA synthesis 
in a wide spectrum of marine bacterial isolates. This mixture retarded cell growth for 18 to $24 \mathrm{~h}$ at a lower inhibitor concentration $\left(5.5 \mathrm{mg} 100 \mathrm{ml}^{-1}\right.$ ) than the one used here (20 mg $100 \mathrm{ml}^{-1}$ ).

The results of the induction experiments did show that, with manipulation, a large fraction of the in situ bacterial assemblage could increase its ETS activity and so be identified as metabolically active using the CTC method. At $20^{\circ} \mathrm{C}$, enhancement of the percentage of CTC+ cells was on the order of 20 - to 40 -fold compared to the time 0 value (Tables $2 \& 3$ ). Even the unamended control treatments showed an increase in \% CTC+, which may imply that the inhibitor compounds per se, added at a combined concentration of $20 \mathrm{mg}$ dry weight $\mathrm{l}^{-1}$, had some stimulatory effect on the bacteria. Addition of mixed amino acids and of yeast extract resulted in the largest increases in percent ETS-active cells at $20^{\circ} \mathrm{C}$. Using the more conservatively derived values presented in Table 3 , amino acid addition induced an increase in \% CTC+ cells from 1.9 to $87 \%$ in May, and from 2.4 to $83.2 \%$ in June. Addition of inorganic nutrients: phosphorus and ammonium, did not cause enhancement of \% CTC+ above the control values. It appeared that in our experiments ETS activity was selectively stimulated by energy-rich organic substrates.

Temperature had a profound effect on the pattern of induction of high ETS activity in bacterial cells. At $20^{\circ} \mathrm{C}$, the maximum abundance of CTC+ cells at the beginning of exponential growth was found by 21.5 to $33 \mathrm{~h}$, while at in situ temperature maximum increase in percentage of CTC+ cells, and the onset of cell growth, did not occur until 72 to $107 \mathrm{~h}$ (Table 2). In addition to a longer lag time compared to the $20^{\circ} \mathrm{C}$ results, at the cooler temperatures the percentages of ETS-active cells were less, the minimum abundances of CTCcells were greater, and addition of amino acids and of yeast extract had a negative rather than a positive effect on the percentage of CTC+ cells (Tables $2 \& 3$ ).

These results are cautionary for future experimentation designed to examine induction of bacterial activity with added substrate. In the June 1997 experiment, a change of less than $4^{\circ} \mathrm{C}$ yielded very different results, not only quantitatively but also in the qualitative pattern of response to added substrates (Tables 2 \& 3). The temperature dependence of our results is in line with other recent reports showing strong temperature dependence of bacterial growth rate (Hoch \& Kirchman 1993, Shiah \& Ducklow 1994, Felip et al. 1996, Kirchman \& Rich 1997) at environmental temperatures less than $20^{\circ} \mathrm{C}$. However, our finding that addition of amino acids and yeast extract was inhibitory to bacterial metabolism at the lower temperatures is opposite to the conclusion of Wiebe et al. (1993) that growth of mesophilic marine bacteria was stimulated at temperatures $<20^{\circ} \mathrm{C}$ by addition of proteose peptone plus yeast extract at concentrations up to $1500 \mathrm{mg} \mathrm{l}^{-1}$ (600 $\mathrm{mg} \mathrm{C}^{-1}$ ).

The results of our study are also cautionary with respect to the design of experiments intended to determine what factors limit bacterial activity in situ. As mentioned earlier, previous studies have typically been 'grow-up' experiments, in which growth response of bacterioplankton is evaluated in response to nutrient addition (Kirchman 1990, Coffin et al. 1993, Shiah \& Ducklow 1994, Carlson \& Ducklow 1996, Cherrier et al. 1996). In such 'grow-up' studies, any factor which is limiting to the portion of the bacterial assemblage which has the highest growth potential could be erroneously interpreted as limiting for the whole assemblage. Thus, the limiting factors for those bacteria which are slow-growing cannot be easily assessed in such experiments. There are 2 issues with respect to 'limiting factors' for marine bacteria: (1) factors that are physiologically limiting to the cells present in a bacterioplankton assemblage at any one time, and (2) factors that are ecologically limiting with respect to maximal potential growth rate and biomass accumulation of bacteria, regardless of what portion of the in situ assemblage is capable of growing up in response to an added nutrient. 'Grow-up' experiments evaluate ecological limitation, while 'turn-on' experiments such as the ones described here evaluate physiological limitation. The difference between these 2 types of limitation could explain the discrepancy in response between the results of Wiebe et al. (1993) for isolated strains of bacteria and our results for the entire bacterial assemblage.

A useful addition to future induction experiments such as those carried out here would be the comparison of the relative taxonomic composition of the bacterial assemblage via molecular genetic approaches, during the time course incubations. Demonstration that the bacterial taxonomic composition did not change with increasing \% CTC+values would provide definitive proof that all components of the bacterial assemblage were induced to high metabolic activity, rather than just some taxonomic components of the assemblage. However, the fact that high \% CTC+ values, and low \% CTC-values, were found before significant increase in total bacterial numbers in our induction experiments is not compatible with 'cryptic growth' of only some components of the assemblage.

Another implication of our results is that in order to determine the physiological response of bacterial cells to added substrate, it is imperative to carry out time series sampling. The timing of enhanced metabolic activity was variable both in terms of type of addition and of incubation temperature (Figs. $3 \& 4$, Tables $2 \&$ $3)$. Significant increase in the abundance of cells iden- 
tified as highly active (CTC+) occurred just prior to increase in total cell abundance.

Previous studies have suggested that bacteria which can reduce sufficient CTC to be identified as having ETS activity are actively growing and are in good physiological condition (Choi et al. 1996, del Giorgio et al. 1998, Sherr et al. 1999, in this issue). We do not know, however, whether some portion of the CTCcells are also growing, perhaps more slowly than the CTC + cells. Other methods of evaluating metabolic activity: cell-specific uptake of radiolabeled substrates and cell-specific RNA content, typically show an order of magnitude or greater number of bacteria that appear to be active compared to the CTC assay. These cells are probably included in the portion of cells that we found were initially $\mathrm{CTC}-$, but were induced to become CTC+ with incubation.

In many systems a substantial fraction of bacterial cells has been shown to have damaged membranes (Porter et al. 1995, Choi et al. 1996, Williams et al. 1997, del Giorgio et al. 1998). Zwiefel \& Hagström (1995) and Heissenberger et al. (1996) have also suggested that some portion of bacterial cells are empty, i.e. cell 'ghosts'. Does the fraction of membrane damaged and ghost cells correspond to the fraction of cells in our study that never became CTC+? An alternative explanation for CTC - cells is that some bacterial strains may not be capable of reducing this compound to the fluorescent formazan. However, we have tested a total of 24 bacterial isolates from the Oregon coast, including alpha and gamma proteobacteria, gram positive bacteria, and flexibacteria, and found that actively growing cultures of each of these strains were equally good at reducing CTC (Sherr et al. 1999).

\section{CONCLUSIONS}

The most significant result of our induction experiments was that, even though the number of identifiably ETS-active bacteria was low ( 2 to $4 \%$ ) when initially sampled, a large percentage of cells originally present in the bacterial assemblage (up to $87 \%$ ) were capable of becoming visibly CTC+ within about 20 to 30 h (Tables $2 \& 3$ ).

Our results demonstrate that the low abundance of ETS-active cells typically found for bacterioplankton in natural waters does not mean that it is only these cells that are capable of metabolic activity. Based on the data presented here, we interpret the CTC+ assay as identifying those cells which are highly ETS active. A large proportion of CTC-cells may have insufficient metabolic activity to be identified as CTC+. Such cells are apparently capable of becoming highly ETS active with sufficient incubation time, increased temperature, and addition of high concentration (100 $\mathrm{mg} \mathrm{C}^{-1}$ ) of organic substrate. Those cells that were originally CTC-, and were subsequently induced to high ETS activity, may have been in a dormant or starvation-survival state (Kjelleberg et al. 1993, Koch 1997, Morita 1997).

The fact that a large fraction of in situ bacterial cells was able to become sufficiently metabolically active to be scored as positive in the CTC assay highlights the need to understand the factors that are physiologically limiting to bacteria in situ. Temperature was identified in this study as an important control. The relatively high concentration of organic substrate (100 $\mathrm{mg} \mathrm{C}^{-1}$ ) that was required for an enhancement of \% CTC+ above the values for the no-addition treatments at $20^{\circ} \mathrm{C}$ may indicate that some in situ bacteria grow best in rich conditions and become dormant or enter a state of starvation-survival when substrate concentrations drop below optimally high amounts. Grazing by bacterivorous protists, which has been shown to selectively remove larger bacterial cells (Gonzalez et al. 1990), dividing bacteria (Sherr et al. 1992), and CTC+ bacteria (del Giorgio et al. 1996), is likely also to be significant in controlling the abundance of the highly ETS-active cells in situ. The issue is complex, involving the interaction of temperature, substrate quantity and quality, and mortality, and will require additional investigation in order to be resolved.

Acknowledgements. This work was supported by NSF grant OCE-9633712 to B.F.S. and E.B.S. We thank Hugh Ducklow and 3 other reviewers for their comments on this manuscript.

\section{LITERATURE CITED}

Carlson CA, Ducklow HW (1996) Growth of bacterioplankton and consumption of dissolved organic carbon in the Sargasso Sea. Aquat Microb Ecol 10:69-85

Cherrier J, Bauer JE, Druffel ERM (1996) Utilization and turnover of labile dissolved organic matter by bacterial heterotrophs in eastern North Pacific surface waters. Mar Ecol Prog Ser 139:267-279

Choi JW, Sherr EB, Sherr BF (1996) Relation between presence-absence of a visible nucleoid and metabolic activity in bacterioplankton cells. Limnol Oceanogr 41:1161-1168

Coffin RB, Connolly JP, Harris PS (1993) Availability of dissolved organic carbon to bacterioplankton examined by oxygen utilization. Mar Ecol Prog Ser 101:9-22

del Giorgio PA, Scarborough G (1995) Increase in the proportion of metabolically active bacteria along gradients of enrichment in freshwater and marine plankton: implications on estimates of bacterial growth and production rates. J Plankton Res 17:1905-1924

del Giorgio PA, Gasol JM, Mura P, Vaque D, Duarte CM (1996) Protozoan control of the proportion of metabolically active bacteria in coastal marine plankton. Limnol Oceanogr 41:1169-1179

del Giorgio PA, Prairie YT, Bird DF (1997) Coupling between 
rates of bacterial production and the number of metabolically active cells in lake bacterioplankton, measured using CTC reduction and flow cytometry. Microb Ecol 34: $144-154$

Douglas DJ, Novitsky JA, Fournier RO (1987) Microautoradiography-based enumeration of bacteria with estimates of thymidine-specific growth and production rates. Mar Ecol Prog Ser 36:91-99

Dufour P, Colon M (1992) The tetrazolium reduction method for assessing the viability of individual bacterial cells in aquatic environments: improvements, performance and applications. Hydrobiologia 232:211-218

Felip M, Pace ML, Cole JJ (1996) Regulation of planktonic bacterial growth rates: the effects of temperature and resources. Microb Ecol 31:15-28

Gasol JM, del Giorgio PA, Massana R, Duarte CM (1996) Active versus inactive bacteria: size-dependence in a coastal marine plankton community. Mar Ecol Prog Ser 128:91-97

Gonzalez JM, Sherr EB, Sherr BF (1990) Size-selective grazing on bacteria by natural assemblages of estuarine flagellates and ciliates. Appl Environ Microbiol 56:583-589

Heissenberger A, Leppard GG, Herndl GJ (1996) Relationship between the intracellular integrity and the morphology of the capsular envelope in attached and free-living marine bacteria. Appl Environ Microbiol 62:4521-4528

Hoch MP, Kirchman DL (1993) Seasonal and inter-annual variability in bacterial production and biomass in a temperate estuary. Mar Ecol Prog Ser 98:283-295

Jepras RI, Carter J, Pearson SC, Paul FE, Wilkinson MJ (1995) Development of a robust flow cytometric assay for determining numbers of viable bacteria. Appl Environ Microbiol 61:2696-2701

Joux F, LeBaron P (1997) Ecological implications of an improved direct viable count method for aquatic bacteria. Appl Environ Microbiol 63:3643-3647

Karner M, Fuhrman JA (1997) Determination of active marine bacterioplankton: a comparison of universal 16s IRNA probes, autoradiography, and nucleoid staining. Appl Environ Microbiol 63:1208-1213

Kirchman DL (1994) The uptake of inorganic nutrients by heterotrophic bacteria. Microb Ecol 28:255-271

Kirchman DL, Rich JH (1997) Regulation of bacterial growth rates by dissolved organic carbon and temperature in the equatorial Pacific Ocean. Microb Ecol 33:11-20

Kjelleberg S, Flardh KBG, Nystrom T, Moriarty DJW (1993) Growth limitation and starvation of bacteria. In: Ford TE (ed) Aquatic microbiology. Blackwell Science Publishers, Boston, p 289-320

Koch AL (1997) Microbial physiology and ecology of slow growth. Microb Mol Biol Rev 61:305-318

Kogure K, Simidu U, Taga N (1984) An improved direct viable count method for aquatic bacteria. Arch Hydrobiol 102: $117-122$

Kogure K, Simidu U, Taga N, Colwell RR (1987) Correlation of direct viable counts with heterotrophic activity for marine bacteria. Appl Environ Microbiol 53:2332-2337

Lopez-Amoros R, Comas J, Vives-Rego J (1995) Flow cytometric assessment of Escherichia coli and Salmonella typhimurium starvation-survival using Rhodamine 123, propidium iodide, and oxonol. Appl Environ Microbiol 61: $2521-2526$

Lovejoy C, Legendre L, Klein B, Tremblay JE, Ingram RG, Therriault JC (1996) Bacterial activity during early winter

Editorial responsibility: David Karl

Honolulu, Hawaii, USA mixing (Gulf of St. Lawrence, Canada). Aquat Microb Ecol $10: 1-13$

McFeters GA, Yu FP, Pyle BH, Stewart PS (1995) Physiological assessment of bacteria using fluorochromes. J Microbiol Methods 21:1-13

Morita RY (1997) Bacteria in oligotrophic environments Chapman and Hall, New York

Newell SY, Fallon RD, Tabor PS (1986) Direct microscopy of natural assemblages. In: Poindexter JS, Leadbetter ER (eds) Bacteria in nature. Plenum Publishing, New York p $1-48$

Pedrós-Alió C, Newell SY (1989) Microautoradiographic study of thymidine uptake in brackish waters around Sapelo Island, Georgia, USA. Mar Ecol Prog Ser 55:83-94

Porter J, Diaper J, Edwards C, Pickup R (1995) Direct measurements of natural planktonic bacterial community viability by flow cytometry. Appl Environ Microbiol 61: $2783-2786$

Posch T, Pernthaler J, Alfrieder A, Psenner R (1997) Cell-specific respiratory activity of aquatic bacteria studied with the tetrazolium reduction method, cyto-clear slides, and image analysis. Appl Environ Microbiol 63:867-873

Rodriguez GG, Phipps D, Ishiguro K, Ridgway HF (1992) Use of a fluorescent redox probe for direct visualization of actively respiring bacteria. Appl Environ Microbiol 58: $1801-1808$

Sherr BF, Sherr EB, MCDaniel J (1992) Effect of protistan grazing on the frequency of dividing cells in bacterioplankton. Appl Environ Microbiol 58:2381-2385

Sherr BF, del Giorgio P, Sherr EB (1999) Estimating abundance and single-cell characteristics of respiring bacteria via the redox dye CTC. Aquat Microb Ecol 18:117-131

Shiah FK, Ducklow HW (1994) Temperature and substrate regulation of bacterial abundance, production and specific growth rate in Chesapeake Bay. Mar Ecol Prog Ser 103: $297-308$

Suzuki M, Sherr EB, Sherr BF (1993) DAPI direct counting underestimates bacterial abundances and average cell size compared to AO direct counting. Limnol Oceanogr 38:1566-1570

Tabor PS, Neihof RA (1984) Direct determination of activities for microorganisms of Chesapeake Bay populations. Appl Environ Microbiol 48:1012-1019

Ullich S, Karrasch B, Hoppe HG, Jeskulke K, Mehrens M (1996) Toxic effects on bacterial metabolism of the redox dye 5-cyano-2,3-ditolyl tetrazolium chloride. Appl Environ Microbiol 62:4587-4593

Wiebe WJ, Sheldon WM, Pomeroy LR (1993) Evidence for an enhanced substrate requirement by marine mesophilic bacterial isolates at minimal growth temperatures. Microb Ecol 25:151-160

Williams SC, Hong Y, Danavall DCA, Howard-Jones MH, Gibson D, Frischer ME, Verity PG (1998) Distinquishing between living and nonliving bacteria: evaluation of the vital stain propidium iodide and the combined use with molecular probes in aquatic samples. J Microbiol Methods $32: 236-255$

Zimmermann R, Iturriaga R, Becker-Birck J (1978) Simultaneous determination of the total number of aquatic bacteria and the number thereof involved in respiration. Appl Environ Microbiol 36:926-935

Zweifel UL, Hagström $\AA$ (1995) Total counts of marine bacteria include a large fraction of non-nucleoid-containing bacteria (ghosts). Appl Environ Microbiol 61:2180-2185

Submitted: March 24, 1998; Accepted: November 4, 1998

Proofs received from author(s): July 13, 1999 